\title{
Yapı İşleri Saha Uygulamalarının İş Güvenliği Risklerinin Değerlendirilmesi ve Önleyici Kontrol Metodu Uygulaması
}

\begin{abstract}
Abdul Vahap KORKMAZ 1
Özet

İnşaat sektöründeki faaliyetler, son yüzyılda yükselen teknoloji ile birlikte önemli gelişmeler göstermektedir. İnşaat ve yapı sektöründeki teknolojik gelişmeler ve yenilikler inşaat sektöründe kullanılan ekipmanların ve malzemelerin de değişmesine yol açmaktadır. İnşaat işçileri genellikle sürekli aynı işyerinde çalışmaktan ziyade sık sık iş değiştirmek, çalıştıkları her işte ancak birkaç haftayla birkaç ay arasında bulunmak zorunda kalan çalışanlardır. Bu durum çalışan ve iş açısından çeşitli olumsuzlukları içermektedir. Çalışanların eğitim ve güvenlik algı düzeyleri ve işyerlerinin güvenlik anlayışları değişken olabilmektedir. Çoğu zaman inşaat çalışanları yılın tamamını çalışarak geçirememektedirler. Bunu telafi etmek için sıklıkla fazla mesai, aşırı çalışma gibi zor koşullarla yüz yüze kalmaktadırlar. Deneyimsiz oldukları işleri yapmak zorunda kalabilmektedirler. Bu durum yeni iş kazaları olasılıklarını da beraberinde getirmektedir. $\mathrm{Bu}$ çalışmada iş güvenliği riskleri değerlendirilerek sunulan önleyi kontrol metodu sayesinde endüstriye zarar veren gereksiz yaralanmaların ve ölümcül iş kazalarının azalacağı düşünülmektedir. Ayrıca bu çalışma kazaların ana nedenlerini tespit etmemize yardımcı olmakla birlikte tehlikelerin nasıl ortadan kaldırılacağını ve risklerin nasıl kontrol edileceğini açıklamaktadır.
\end{abstract}

Anahtar Kelimeler: Yapı İşleri, Saha Uygulamaları, Risk, İş Güvenliği, Kontrol Metodu.

\section{The Evaluation of Occupational Safety Risks of Structure Works And Practice Control Method Application}

\begin{abstract}
The activities in the construction sector show significant developments in the last century along with the rising technology. Technological developments and innovations in the construction and construction sector lead to a change in the equipment and materials used in the construction sector. Construction workers are often employees who are frequently forced to change their jobs rather than working in the same workplace, but only in a few weeks and months. This situation includes various negativities in terms of employee and job. The level of education and safety perception of the employees and the safety understanding of the workplaces can be variable. Most of the time, construction workers cannot spend the whole year working. To compensate for this, they often face extreme conditions such as overtime, overwork. They may have to do what they
\end{abstract}

${ }^{1}$ Dr., Esan Madencilik, Eskișehir

İlgili yazar / Corresponding author: av.korkmaz@hotmail.com

Bu makaleye atıf yapmak için- To cite this article Korkmaz A.V. (2019). Yapı İşleri Saha Uygulamalarının İş Güvenliği Risklerinin Değerlendirilmesi Ve Önleyici Kontrol Metodu Uygulaması. Afet ve Risk Dergisi, 2(1), 20-31. 

it is thought that unnecessary injuries and fatal occupational accidents which harm the industry will be decreased by means of the preventive control method which is evaluated by occupational safety risks. In addition, this study helps us identify the main causes of accidents and explains how to eliminate hazards and control risks.

Keywords: Construction, Field Applications, Risk, Occupational Safety, Control Method

\section{GíRiş}

Çoğu sanayileşmiş ülkede inşaat sektörü, gayri safi yurtiçi hasılaya (GSYİH) katkı açısından en önemli sektörlerden biridir. Ayrıca çalışanların sağlığı ve güvenliği üzerinde önemli bir etkisi vardır. İnşaat sektörü hem ekonomik hem de sosyal açıdan önemlidir (Yoon vd., 2013). İnşaatta, işçiler her biri belirli bir risk ile bağlantılı çok çeşitli faaliyetler gerçekleştirirler. Bir görevi yerine getiren işçi, doğrudan işi ile ilişkili risklere maruz kalmaktadır ve yakın çalıştığı iş arkadaşları tarafından ayrıca üretilen risklere pasif olarak maruz bırakılmaktadır (Pinto vd., 2011). Mimari yapı tasarımları, kullanılan materyaller, boyutları ve saha koşulları genellikle her projede değişen bir öğrenme eğrisi gerektirir. Bu değişiklikler sonucu ortaya çıkan riskler nedeniyle ölümlü kazalar, yaralanmalar, sürecin her bir yerinde ve çeşitli şekillerde meydana gelebilir (Grant, 2014).

Bu durumun bir sonucu olarak, inşaatta yüksek bir kaza sıklığı vardır ki bu da onu güvensiz bir endüstri haline getirmektedir. İnșaat sektöründe güvenlik derecesi, tek bir kaza ile değil, belirli bir zaman aralığı içinde meydana gelen bir dizi kaza ile belirtilir. Güvenlik düzeyini ve değişikliklerin yönünü değerlendirmek için kazalarda gözle görülür eğilimler hakkında bilgi sahibi olunması gerekmektedir (Hola ve Szostak, 2014).

Gelișen ve yükselen teknoloji içinde çalışan, üretken insanların her gün karşılaștıkları konu iş kazalarıdır. Bunlardan korunmak ve kaçınmak, ancak "iş sağlı̆̆ı ve güvenliği" tedbirlerinin, kurallarının bilinmesi ve uygulanması ile mümkündür.

Yapı işlerinin güvenlik riskleri çalışma koşullarına göre, günden güne, hatta saatten saate değişebilmektedir. Çalışma ortamında aralıklı ya da tekrarlanan riskler mevcuttur. Çalışan kendi yaptı̆̆ işin yanı sıra çalışma ortamındaki diğer işlerden kaynaklanan risklerden de etkilenir. Her bir maruziyet, tehlikenin şiddeti ve yapılan ișin süresine bağlıdır (Nyirenda vd., 2015).

Bununla birlikte, inşaatta İSG ile ilgili yapılan bilimsel çalışmalar on beş yll öncesine kadar çok azdı. 2001'den sonra inşaat ile ilgili İSG yayınlarının sayısı oldukça artmıştır. Farklı perspektiflerden ve farklı araçlardan yararlanarak araştırmacılar inşaatta mesleki tehlikeler üzerinde çalışmışlardır. İnşaat sektöründe iş kazalarını araştırmak ve anlamak için birçok araç ve yöntem bulunduğu belirtilmektedir (Sousa vd., 2014).

Ülke genelinde yaklaşık 6,5 milyon insan olmak üzere farklı inşaat alanlarında her gün yaklaşık 252.000 kişi çalışmaktadır. İnşaat sektörü için ölümcül yaralanma oranı, tüm sektörler için bu kategorideki ulusal ortalamanın üzerindedir (Akboğa, 2014).

İnşaat işçileri için potansiyel tehlikeler şunlardır:

- Düşmeler (takılma veya yüksekten);

- Yapı temelinin çöküşü;

- İskele çökmesi;

- Elektrik şok ve ark flaş / ark patlaması;

- Uygun kişisel koruyucu ekipmanın kullanılmaması ve Devinimsel hareket yaralanmaları. 
Yapı İsleri Saha Uygulamalarının İs Güvenliği Risklerinin Değerlendirilmesi Ve Önleyici Kontrol Metodu Uygulaması Geçmişten günümüze kadar pek çok alanda uygulana gelmiş risk değerlendirme yöntemlerinden biriside kontrol listeleri metodudur. Hazırlanması ve uygulanması oldukça kolay olan metot başlıca üç temel adımdan oluşmaktadır (Saat, 2009).

Hazırlık safhası; Mevzuat ve işletme incelenerek kontrol listeleri hazırlanmaktadır.

Uygulama safhası; Hazırlanan listeler işletmeye uygulanmaktadır.

Değerlendirme safhası; Alınan sonuçlar uygun, uygun değil kararları ile değerlendirilir ve uygunsuzlukların giderilmesi sağlanmaktadır. Kontrol listesi metodunun hazırlanması kolaydır. Risk değerlendirmesinin yapılacağı sektöre ve işletmenin özelliklerine göre sorular oluşturulmakta ve kolayca uygulanabilmektedir. Uygulama safhasında derin bilgi ve tecrübeye gerek yoktur, sorular tecrübesiz ve sektörde az deneyimi olan bir çalışanlar tarafından bile cevaplanabilmektedir. Kontrol listesi metodu ile en temel tehlike kaynakları rahatlıkla belirlenip riskler değerlendirilebilmektedir. Bu sebeple matris metodu, Fine - Kinney Metodu, hata türleri etkileri analizi ve diğer nicel risk değerlendirme metodları ile birlikte kullanılarak çalışmaya katkı sağlayabilir. Hazırlanma ve uygulama sürecinde kalabalık bir ekip çalışmasına gerek yoktur, bir veya iki mühendis ve teknik eleman tarafından kontrol listesi hazırlanıp sahaya uygulanabilmektedir (Saat, 2009).

Çeşitli kaynaklarda hazır kontrol listelerinin olması, hazırlık aşamasında uzun bir literatür taramasına gerek duyulmamasını sağlamaktadır. Soruların ne kadar detaylandırılacağına karar verildikten sonra kontrol listesi kısa sürede oluşturulabilmektedir. Bu çalışmada İş sağlı̆̆ı ve güvenliği risk değerlendirmesi metodlarından kontrol listesi metodu bir çimento fabrikasına ait inşaat şantiyesinde uygulanmıştır. Yapı şantiyesinde çalışan işçiler ve teknik yönetim ekibi ile görüşülerek kontrol metodu paremetreleri oluşturulmuş ve çalışmada detaylıca açıklanmıştır.

\section{YAPI CALIŞMA SAHALARI TEHLİKELERİN DEĞERLENDİRİLMESİ VE ÇÖZÜM ÖNERİLERİ}

Occupational Safety and Health Administration (OSHA) standartlarına göre inşaat işleri için, en çok atıflara dahil edilen 10 OSHA standardı şunlardır (Zhou vd., 2015)

1. Yapı iskelesi

2. Düşmeler (kapsam, uygulama, tanımlar)

3. Keșifler (genel gereksinimler)

4. Merdivenler

5. Ana koruma

6. Keşifler (koruyucu sistemler için gereklilikler)

7. İletișim

8. Düşme koruma (eğitim gereksinimleri)

9. İnşaat (genel güvenlik ve sağlık hükümleri)

10. Elektrik (kablolama yöntemleri, tasarım ve koruma).

\subsection{Yapı İskelesi}

İnşaat ve yapı işleri için iskele yapılmadığında veya doğru kullanılmadığında düşme tehlikeleri ortaya çıkabilir. Yaklaşık 2.3 milyon inşaat iş̧̧isi iskeleler üzerinde sıklıkla çalışmaktadır. İnşaat ve yapı işçilerinin iskele ile ilgili kazaların önüne geçilmesi ve risklerin en aza indirgenmesi, her yıl tahmini 4.500 yaralanma ve 50 ölümün önlenmesini sağlayacaktır. İnşaat için kullanılan iskeleler kendi ağırlığının 4 katını taşıyabilecek sağlamlıkta olmalıdır ve sağlam zemin üzerine montajı yapılmalıdır (Gürcanlı ve Müngen, 2013). Kalas, çubuk, varil, eski tuğla veya beton bloklar gibi taşıyıcılar, çelik iskeleleri veya ahşap iskeleleri desteklemek için kullanılmamalıdır (Gürcanlı, 2015). 


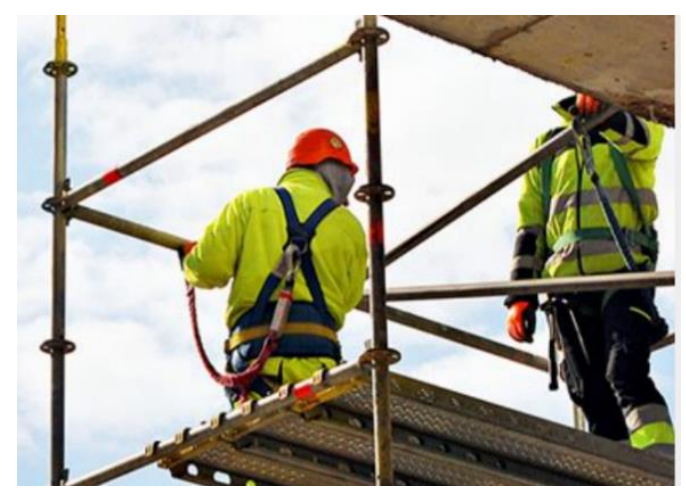

Şekil 1. Yapı iskelesi platformu güvenli çalışma örneği

\subsection{Düşme}

Düşmeler, her yıl inşaat sektöründeki en büyük ölüm sayısını tutarlı bir şekilde yansıtmaktadır. Dengesiz çalışma yüzeyleri, yanlış kullanım veya düşmeye karşı koruma ekipmanı ve insan hatası ve iş gücü kullanımımdaki başarısızlık da dâhil olmak üzere, birçok faktör sonucunda genellikle düşmeler meydana gelmektedir. Yapılan son teknik araştırmalar ve sektörel çalışmalar korkuluklar, düşmeyi engelleme sistemleri, güvenlik ağları, kapaklar ve emniyet sistemlerinin kullanılmasının birçok ölüm ve yaralanmaların azalmasını sağlayabileceğini ortaya çıkarmıştır (Gürcanlı ve Müngen, 2005). Daha güvenli çalışma yüzeyleri sağlamak için hava ile aktarmalı asansörler veya yükseltilmiş platformlar kullanılmalıdır. İşçiler çatıların kenarlarına yakın yerlerde çalışırken düşmelerden korumak için zemin panolarına ve çevreye renkli uyarıcı işaret ve levhalar gibi kontrol hattı sistemleri kurmaları gerekmektedir.

Tavan taban delikleri emniyet şeridi ile etrafı kapatılmalıdır ve uyarıcı bir levha konulmalıdır. Düşmeye karşı güvenlik ağ sistemlerini veya kişisel düşmeyi durdurma sistemleri (vücut koşumları) kullanılmalıdır (Gürcanlı ve Müngen, 2005).

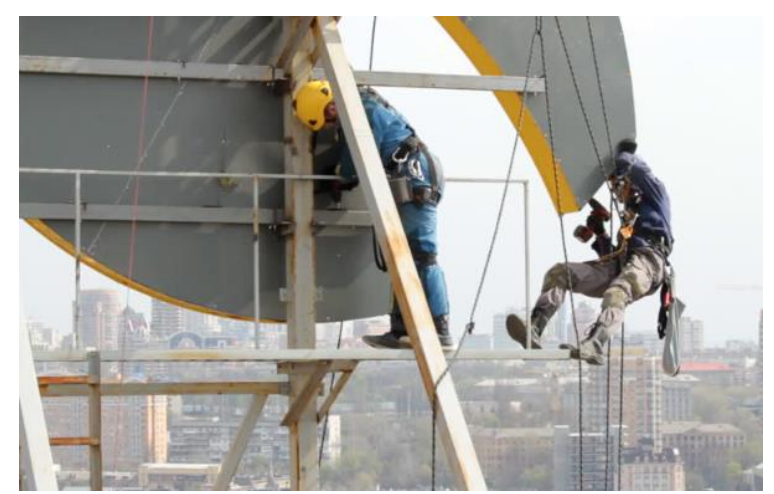

Şekil 2. Yüksekte çalışma örneği

Seviye farkı bulunan ve düşme sonucu yaralanma ihtimalinin oluşabileceği her türlü alanda yapılan çalışma; yüksekte çalışma olarak kabul edilir. Yüksekte yapılması zorunlu olmayan montaj ve benzeri çalışmaların mümkün olduğunca öncelikle yerde yapılması sağlanmalıdır. Yapılacak çalışmaların önceden planlanması ve organize edilmesi, bu planlama yapılırken yüksekten düşme ile ilgili hususlara acil durum planında yer verildiğinden emin olunması sağlanmalıdır. Çalışanların, çalışma yerlerine güvenli bir şekilde ulaşmaları uygun araç ve ekipmanlarla sağlanmalıdır (Gürcanlı ve Müngen, 2004).

\subsection{Merdivenler}

Merdivenler ve merdiven boşlukları inşaat işçileri arasında başka bir yaralanma ve ölüm kaynağıdır. OSHA, merdivenlerde düşme ve inşaatta kullanılan merdivenler nedeniyle yılda 
Yapı İsleri Saha Uygulamalarının İs Güvenliği Risklerinin Değerlendirilmesi Ve Önlevici Kontrol Metodu Uygulaması 24,882 yaralanma ve 36 ölümün olduğunu tahmin ediyor. Bu yaralanmaların yaklaşık yarısı, mesai saati dışındaki zamanı da kapsayacak kadar ciddi boyutlardadır (Gürcanlı, 2008). Çalışma yapılacak iş için uygun merdiven seçilmelidir. Yetkili bir kişiyi merdiveni kullanmadan önce herhangi bir kusur olup olmadığını görsel olarak incelemelidir. Merdiven üzerinde yapısal hasar, bölünmüş̧/bükülmüş yan raylar, kırık veya eksik basamaklar/adımlar/ tutucular ve eksik veya hasarlı güvenlik aygitları olup olmadığı kontrol edilmelidir. Kaymalara veya düşmelere neden olabilecek yăg, kir veya diğer kirleticiler varsa merdivenler temizlenmeli ve güvenliğinden emin olunduktan sonra kullanılmalıdır. Olası kusurları gizleyebilecek boya veya çıkartmalar (uyarı etiketleri hariç) kullanılmamalıdır. Merdivenlerin çalışma alanına güvenli bir şekilde ulaşmak için yeterince uzun olduğundan emin olunmalıdır. Tamir veya değiştirme için marka veya etiket "Kullanmayın" taşıyan hasarlı veya arızalı merdivenler kullanılmamalıdır ve ortadan kaldırılmalıdır. Yük merdiveni maksimum amaçlanan yükün ötesinde veya üreticinin nominal kapasitesinin ötesinde kullanılmamalıdır. Merdivenin yük derecesinin, malzeme ve aletler de dahil olmak üzere kullanıcının ağırlığını taşıyabileceğinden emin olunmalıdır. Elektrik işleri ve enerji hatlarının yakınında metalik bileşenlere sahip merdivenler kullanmaktan kaçınılmalıdır (Gürcanll, 2008).

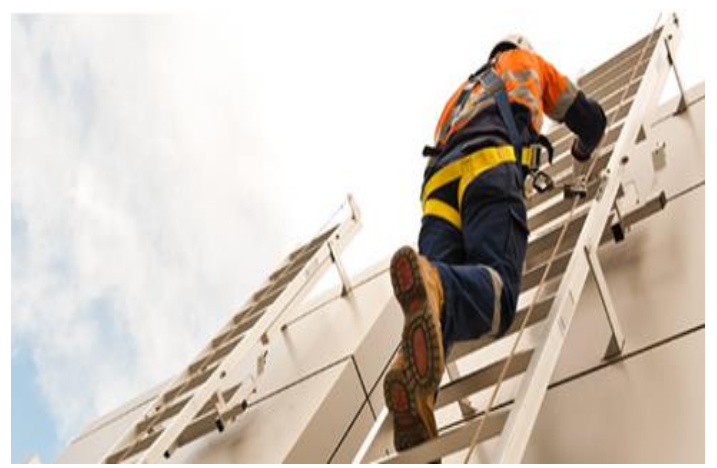

Şekil 3: Merdiven ve basamaklarda güvenli çalışma örneği

\subsection{Yürüyüs Yolları}

İnşaat işçilerinin çalışma esnasında zeminde kaymalar, yürüyüş yollarında takılmalar ve portatif elemanların düşmesi büyük bir yaralanma ve ölüm kaynağıdır (Mayhew, 2003). Araç nakil yolları ve yürüme yolları tehlikeli nesnelerden, çöplerden ve malzemelerden arındırılmış olmalıdır. Kaygan ıslak nemli merdivenler, seyyar ekipmanlar yürüme yollarında tehlike arz eden nesneler ivedi olarak düzeltilmelidir. Basamakların tüm adımı ve inişi kapsadığından emin olunmalıdır. Dört veya daha fazla yükselticiye sahip veya 30 inçten fazla yükselen merdivenler en az bir el parmak genişliğine sahip olmalıdır (Mayhew, 2003).

\subsection{Kazı İşleri}

Kazı işleri esnasında zemin çökmeleri her yıl onlarca ölüme ve yüzlerce yaralanmaya neden olur. Kazı işleri sonucu meydana gelen ölümler 2018 yılında hayli yükselmiștir (Gürcanlı, 2011). Kişisel koruyucu ekipmanlar kullanılmadan kazı operasyonları esnasında açılan çukur, hendek ve kanal içerisine girilmemelidir. Her zaman derin veya daha büyük hendek ayakları için koruyucu bir sistem kullanılmalıdır. $6 \mathrm{~m}$ derinliğinde veya daha büyük siperlerde koruyucu bir sistem tasarlamak için yetkin bir profesyonel mühendis tarafından hazırlanan proje kullanılmalı ve yetkili mühendisler tarafından kontrol edilmelidir.

\section{Koruma Sistemleri;}

Çalışanları korumak için toprak tipine göre eğimin gereksinimlere göre, hendek duvarını 11 2: 1 yükseklik/ derinlik oranından daha dik olmayacak eğimli bir açıda kesecek şekilde kazı yapılmalıdır. Derinliği 20 metreyi aşmayan siperlerde toprak hareketini önlemek için destekler kurarak işçiler korunmalıdır. Hendek, çukur ve kanal gibi yapılarda çalışan işçileri kolaylıkla 

çıkabilmeleri için $750 \mathrm{~cm}$ yanal yürüyüş sağlayabilecek merdiven vb. yapılar sağlanmalıdır. Payandalar bir hendek kenarından en az iki metre geriye doğru tutulmalıdır. Siperlerin, giriș öncesinde ve yağmur fırtınası, titreșimler veya aşırı ek yükler gibi herhangi bir tehlike olayından önce yetkili bir kişi tarafından kontrol edildiğinden emin olunmalıdır.

Kazı eğimleri;

Toprak tipi ve yatay açıya göre 20 m'den (6,09 m'ye kadar) az olan kazllar için izin verilen maksimum eğimler tablo 1' de gösterilmiştir (Gürcanll, 2011).

Tablo 1. OSHA Teknik El Kitabı, Bölüm V, kazı, kanal açma ve destekleme Tehlike Tanıma

(Görgülü, 2008).

\begin{tabular}{|l|c|c|}
\hline Toprak Tipi & $\begin{array}{c}\text { Yükseklik / } \\
\text { Derinlik Oranı }\end{array}$ & Ĕgim Açısı \\
\hline Stabil Kaya (Granit veya Kum taşı) & Dikey & $90^{\circ}$ \\
\hline Kil & $3 / 4: 1$ & $53^{\circ}$ \\
\hline Çakıl, Silt & $1: 1$ & $45^{\circ}$ \\
\hline Kum & $11 / 2: 1$ & $34^{\circ}$ \\
\hline $\begin{array}{l}\text { Granit veya Kum taşı(Maksimum } \\
12 \text { m'lik kazı derinliği için) }\end{array}$ & $1 / 2: 1$ & $63^{\circ}$ \\
\hline
\end{tabular}

Vinçler kullanımdan önce incelenmediği ve uygun şekilde kullanılmadığı takdirde ölümcül kazalar ve ciddi yaralanmalar meydana gelebilir. Genellikle bu yaralanmalar, bir işçinin bir yüke çarpması veya vinçin dönüş yarıçapı içinde yakalanması durumunda ortaya çıkar. Bir vincin veya yük hattının bomu havada bir güç hattına temas ettiğinde birçok ölümcül iş kazası meydana gelebilir (ÇSGB, 2018). Çalışmaya başlamadan önce emniyetli çalışmak için tüm vinçler kontrol edilmeli arızalı olanlar raporlanmalı ve kullanılmamalıdır. Vincin üzerinde bulunan tel halat, zincir ve kanca kontrol edilerek hasar olup olmadığı tespit edilmelidir. Hasarlı olanlar acilen değiştirilmeli ve hasarlı şekilde kesinlikle kullanılmamalıdır. Vinçin kaldırılacağı yükün ağırlığı bilinmelidir. Yükün, vincin ana kapasitesini aşmadığından emin olunmalıdır. Fren sisteminin dengesini ve etkinliğini doğrulamak için yük birkaç inç yükseltilmelidir. Kullanmadan önce vincin tüm donanımları kontrol edilmeli ve yükün etrafında vinç halatları veya zincirleri sarılmamalıdır. Vincin ayakları eşit şekilde tamamen uzatılmalıdır. Yük işçilerin üzerinden geçirilmemelidir. Vincin dönüş çapı barikatlar ile kapatılmalı ve güvenli bir bölge oluşturulmalıdır. Hava elektrik dağıtım ve iletim hatlarına dikkat edilmeli ve enerjili elektrik hatlarından en az $300 \mathrm{~cm}$ güvenli bir çalışma boşluğu sağlanmalıdır (ÇSGB, 2018).

\subsection{Kimyasal Maddelerle Calıșma}

Kimyasallarla ilgili tehlikelerin fark edilmemesi, kimyasal yanıklara, solunum problemlerine, yangınlara ve patlamaya neden olabilir. Tesiste her kimyasal madde için bir Malzeme Güvenlik Bilgi Formu (MSDS) hazırlanmalıdır. Bu bilgileri çalışanlara her zaman aynı dilde veya etkilenen personel tarafından açıkça anlaşılan formatlarda ulaştırılmalıdır. Çalışanların MSDS'i nasıl okuyacakları ve kullanacakları anlatılmalı ve bu hususta yardımcı olunmalıdır. Tehlikeli kimyasalların kullanımı için üreticinin MSDS talimatları izlenmelidir. Çalışanlar, kullanılan her bir tehlikeli kimyasalın riskleri hakkında bilgilendirilmelidir. Kimyasal maddelerin depolandığ alanlarda döküntü temizleme kitleri sağlanmalıdır. Yazılı bir dökülme kontrol planı hazırlanmalıdır. Çalışanlara döküntüleri temizlemek, kendilerini korumak ve kullanılmış materyalleri uygun şekilde atmak için eğitim verilmelidir. Uygun kişisel koruyucu ekipmanlar sağlanmalı ve kullanımını zorlanmalıdır. Kimyasallar güvenli bir yerde ve güvenli bir şekilde saklanmalıdır (Cameron vd., 2008). 


\subsection{Forkliftler}

Forklift ve iş makinesi operasyonlarına bağlı olarak her yıl yaklaşık 100 çalışan ölümcül kazalara maruz kalmakta, her yıl yaklaşık 95.000 çalıșan ise iş kazası sonucu yaralanmaktadır. Forklifte bağlı iş kazaları, inşaat ve yapı sektöründeki ölümlerin önemli bir kısmını oluşturmaktadır. Çalışanların forklifti güvenli bir şekilde kullandıklarından emin olmak için tüm operatörler eğitilmeli ve yetkililer tarafından onaylanmalıdır. 18 yașın altındaki herhangi bir çalışanın forklift kullanmasına izin verilmemelidir. Lastikler de dahil olmak üzere taşıma ekipmanları düzgün bir şekilde muhafaza edilmelidir. Forklift üreticisinin yazılı onayı olmadan forkliftin kapasitesini ve güvenli çalıșmasını etkileyecek donanımlarının değiştirmemeli ve değiștirilmesine izin verilmemelidir. Kullanmadan önce forklift için yük alma, taşıma, indirme ve istifleme için güvenli işletim prosedürleri takip edilmelidir. Sıkışı veya kaygan yüzey alanlarında yavaşlanmalı asla 5 $\mathrm{km} /$ saat'i geçmemeli, güvenli bir şekilde hareket edilmelidir. Endüstriyel forkliftin kapasitesinden daha ağır yükler kaldırılmamalıdır.

Güvensiz veya arızalı forkliftler bakım için servise alınmalıdır. Forklift operatörleri emniyet kemeri takmadan aracı kullanmamalıdır. Yükseltilmiş yüklerle seyahat edilmemelidir. Devrilme koruyucu yapısının yerinde olduğundan emin olunmalıdır. Geri sinyal alarmının çevreleyen gürültü seviyesinin üzerinde çalıştığından ve duyulduğundan emin olunmalıdır (Hafızoğlu, 2006).

\subsection{Baş Koruma}

Ciddi kafa yaralanmaları kafaya tesir eden darbelerden kaynaklanabilir. İşçilerin, yukarıdan düşen nesneler, sabit nesnelerden kafalarına çarpma veya elektriksel tehlikelerle kazara kafa temasının olduğu yerlerde baret kullandıklarından emin olunmalıdır (Kazan, 2013).

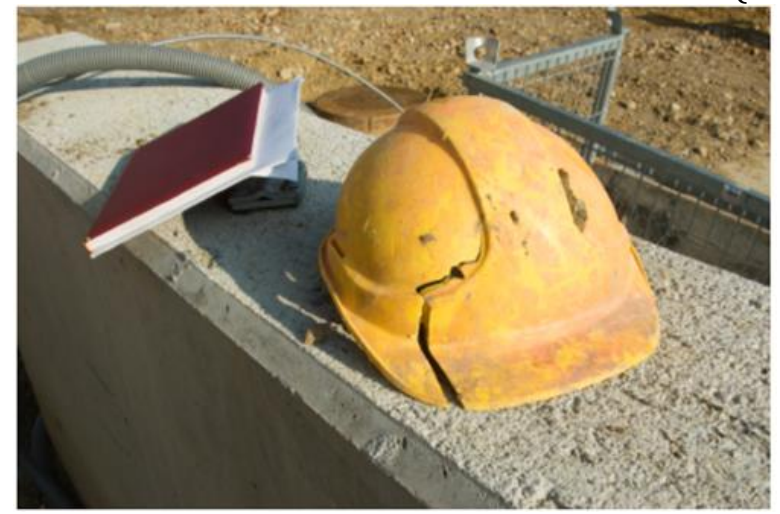

Şekil 4. Yüksekten cisim düşmesi sonucu zarar gören baret

\section{SAHA UYGULAMALARI SONUCU ÖNLEYICI GÜVENLIKK KONTROL PARAMETRELERININ BELIRLENMESI}

Aşağıda belirtilen kontrol listeleri yaralanmalara, hastalıklara ve ölümlere neden olabilecek tehlikeleri önlemek için gerekli adımları atmamıza yardımcı olabilir. Her zaman olduğu gibi, potansiyel bir tehlike ile ilgili endişelerimiz varsa dikkatli olunmalı ve yardım alınmalıdır.

\subsection{Göz ve Yüz Koruma}

Eskimiş güvenlik gözlükleri veya yüz siperleri her zaman, kaynak, kesme, taşlama, çivi ile çalışma esnasında (veya beton ve/veya zararlı kimyasallarla çalışırken veya uçan parçacıklara maruz kalındığında) yabancı cisimlerin göze girmesine neden olabilir. Göz ve yüz koruyucuları, beklenen tehlikelere göre seçilmelidir. Güçlendirilmiş elektrik sistemlerinde çalışmak da dahil olmak üzere herhangi bir elektrik tehlikesine maruz kalınabilecek durumlarda güvenlik gözlükleri veya yüz siperleri takılmalıdır. 


\subsection{Ayak Koruma}

İnşaat işçileri, kaymaz ve delinmeye karşı dayanıklı tabanlı iş ayakkabıları veya botları giymelidir. Ağır donanım veya düșen nesnelerin etrafında çalıșırken ayak parmaklarının ezilmesini önlemek için koruyucu parmaklıklı çelik burunlu ayakkabılar tercih etmelidirler.

\subsection{El Koruma}

Eller koruyucu eldivene rahatça sığmalıdır. İşçiler iş için doğru eldivenleri tercih etmelidirler (örneğin, beton işlerinde kullanılan ağır iş lastik eldivenleri, kaynak için eldivenler ve elektrik tehlikelerine karşı yalıtımlı eldivenler).

\subsection{Baş Koruması}

İşçiler, yukarıdan düşen cisimler, kafalarını sabit nesnelere çarpmalara karşı koruyacak veya elektriksel tehlikelerle kazara temasa maruz kalma potansiyellerine karşı sert ve dayanıklı baretler giymelidir. Baretler rutin olarak ezik, çatlak veya bozulma açısından günlük görsel olarak incelenmelidir. Baretler ağır bir darbe veya elektrik çarpmasından sonra değiştirilmelidir. Baretler sağlam, temiz bir şekilde muhafaza edilmeli ve kullanılmalıdır.

\section{5. İskele}

İskele sağlam bir zeminde ayarlanmalıdır. İskele kuvvetini etkileyen hasarlı parçalar hizmet dışı bırakılmalıdır. İskele çalışma esnasında değiştirilmemelidir. İşçiler mobil olacak şekilde tasarlanmadıkça ve işçiler uygun prosedürler doğrultusunda eğitilmedikçe iskeleler yatay olarak hareket ettirilmemelidir.

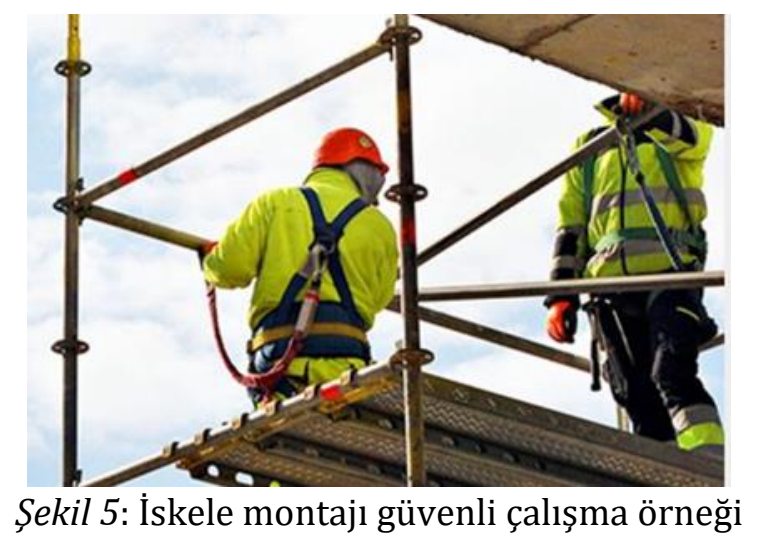

Çalışma ortamı kar, buz veya diğer kaygan malzemelerle kaplandığında iskele üzerinde çalışmalarına izin verilmemelidir. İskeleler enerji hatlarının $10 \mathrm{~m}$ içerisinde kullanılmamalıdır. Yetkili bir kişi, iskelede çalışmanın güvenli olduğuna karar vermedikçe, çalışanların kötü havalarda veya yüksek rüzgârlarda iskeleler üzerinde çalışmalarına izin verilmemelidir. Merdivenler, kutular, variller, kovalar veya diğer derme çatma platformlar çalışma yüksekliğini arttırmak için kullanılmamalıdır. İskele platformlarında ekstra malzeme birikmesine izin verilmemelidir. İskele desteklenecek şekilde tasarlandığından daha fazla ağırlıkla yüklenmemelidir. Kötü hava koşullarının iskeleye olan etkileri kontrol edilmelidir. İskelenin durumu periyodik olarak kontrol edilmelidir.

\subsection{Elektrik}

Yeni ve mevcut enerjili (yüksek ısılı) elektrik devrelerinde, tüm elektrik kapatılıncaya ve topraklama yapılıncaya kadar çalışma yasaklanmalıdır. Bir mevcut kilitleme/etiketleme sistemi olmalıdır. Yıpranmış, hasarlı veya aşınmış elektrik kabloları derhal değiştirilmelidir. Tüm uzatma kablolarının topraklama uçları olmalıdır. Esnek kablolar hasardan korunmalı ve keskin köşeler ve çıkıntılar önlenmelidir. Tüm elektrikli aletler ve ekipmanlar güvenli bir şekilde muhafaza edilmeli 
Yapı İsleri Saha Uygulamalarının İs Güvenliği Risklerinin Değerlendirilmesi Ve Önlevici Kontrol Metodu Uygulaması ve kusurlar için düzenli olarak kontrol edilmelidir. Arızalı ekipmanlar servis dışı bırakılmalıdır. Çalışanları elektrik enerjisiyle temas etmekten korumak için tasarlanmış herhangi bir koruyucu sistem veya cihaz kullanılmalıdır. Enerji hatlarının lokasyonları belirtilmeli ve tanımlanmalıdır. Merdivenlerin, iskelelerin, ekipmanın veya malzemelerin asla elektrik güç hatlarının $300 \mathrm{~cm}$ mesafeye ulaşmadı̆̆ından emin olunmalıdır. Tüm elektrikli aletler çift yalıtımlı tipte olmadıkça uygun şekilde topraklanmalıdır. Çoklu fiş adaptörleri kullanılmamalıdır.

\subsection{Zemin ve Duvar Açıklıkları}

Zemin açıklıkları (12 inç veya daha fazla), her iki tarafa da güvenli bir kapak, bir korkuluk veya eşdeğer tarafından koruyucular yapılmalıdır (merdiven girişleri hariç). Döşeme panosu sürekli olarak kat deliklerin kenarlarına veya etrafına monte edilmelidir (kişi açıklığın altında geçmesi olabilir).

\subsection{Yükseltilmiş Yüzeyler}

İşaretler, uygun şekilde yükseltilmiş yüzey yük kapasitesini göstermelidir. Zemin veya zeminden 48 inçten fazla olan yüzeyler standart korkuluklara sahip olmalıdır. Tüm yükseltilmiş yüzeyler (insanların ya da makinelerin düştüğü nesnelere maruz kalabilecekleri) standart 4 inçlik tomarlara sahiptir. Yükseltilmiş depolama ve çalışma yüzeylerine sabit bir giriş ve çıkış yolu olmalıdır. Malzemeler, devrilmesi, düşmesi, çökmesi, yuvarlanması veya yayılmasını önleyecek şekilde istiflenmelidir.

\subsection{Tehlikeli Maddeler}

İşyerinde kullanılan tehlikeli maddelerin listesi korunmalı ve şantiyede hazır bulundurulmalıdır. Malzeme Güvenlik Bilgi Formlarına (MSDS), etiketlemeye ve çalışan eğitimine yönelik yazılı bir tehlike iletişim programı bulunmalıdır. Tehlikeli bir maddenin her bir kabı (tekneler, șişeler, depolama tankları), ürün kimliği ve bir tehlike uyarısı ile etiketlenmelidir (belirli sağlık tehlikeleri ve fiziksel tehlikeler ile ilgili olarak). Malzeme Güvenlik Veri Sayfaları, kullanılan her bir tehlikeli madde için her zaman hazır bulundurulmalıdır. Tehlikeli maddeler için etkili bir çalışan eğitim programı vardır.

\subsection{Vinç Güvenliği}

Vinçler, herhangi bir elektrik hattının $300 \mathrm{~cm}$ mesafesinde çalıştırılmakla sınırlandırılmıştır. Çalışan insanların üzerinden kaldırılan yükler geçirilmemelidirler. Elektrikli mıknatıslı vinçler kaldırma ve taşımalarda veya sıcak eriyik malzeme taşıma gibi işlerde çalışma sahasında kesinlikle isçilerin bulunmadığından emin olunmalıdır. Elektrikli mıknatıslı vinç, çalışmaz durumda iken, mıknatıslar vinç üzerinde yüksekte bırakılmamalıdır. Bunlar ya doğrudan yere indirilmeli ya da bu iş için yapılmış platformlar üzerine indirilmelidirler. Mıknatıslar kullanılmadıklarında vinç üzerinden çıkartılmalıdırlar. Nominal yük kapasiteleri, çalışma hızı ve talimatları operatöre bildirilmeli ve güncel olmalıdır. Vinçler bir yük şeması ile donatılmıştır. Operatör yük tablosunu anlamalı ve buna göre vinci kullanmalıdır. Operatör, vinç bomunun açısını ve uzunluğunu her zaman belirleyebilmelidir. Vinç makineleri ve diğer sarma ekipmanları, iyi durumda olduğundan emin olmak için kullanımdan önce günlük olarak kontrol edilmelidir. Vinçin dönüş yarıçapındaki erişilebilir alanlar barikatlı olmalıdır. Vinç ve vinç operatörlerine ait el işaretlerinin çizimleri iş̧̧ilerin görebileceği bir panoda yayınlanmalıdır. Yüklerin taşınması, yükseltilmesi ve indirilmeleri uyarıcı işaretlerle ilgili eğitim almış işaretçiler (manevracılar) tarafından gösterilecek el, kol işaretlerine göre yapılmalıdır. Birden fazla işaretçinin görev aldığı operasyonlarda vinç operatörü sadece birinden işaret almalı ve manevracılar tarafından gösterilecek işaretlere uymalıdır. Yükle beraber insanlar kaldırıp taşınmamalıdırlar. Vinç operatörü operasyon esnasında asılı yük durumunda makinayı kesinlikle terketmemelidir. Vinç ayakları gerektiğinde hepsi eşit olacak şekilde uzatılmalıdır. Vinç üzerine görülebilir bir yer ve şekilde vincin en fazla kaldırma kapasitesi yazılmalıdır. Motorlu mobil vinçlerle kaldırılması gereken maksimum yükler operatör kabinlerinin içinde veya dışında yazılı olarak gösterilmeli ve kollu vinçlerde ayrıca yatıklık ve ok mesafelerine göre kaldırılmasına izin verilen maksimum 

yükler, aynı şekilde gösterilmeli ve bunlardan maksimum yükten fazlası kaldırıldığında, ikaz eden ıșıklı ve sesli otomatik bir uyarma tertibatı bulundurulmalıdır. Vincin çalıșma alanı güvenlik șeriti içerisine alınmalı ve geçiş güzergâhına malzeme konmamalıdır. Vinç tamburuna halatların doğru şekilde sarılması sağlanıp, tambur kanalındaki yivlerin üzerine halatların gelerek kesilmelerini önlemek için halat sarıcıları (klavuzları) sağlanmalıdır. Kırık, aşınmış veya hasar görmüş tel halatlar servisten çıkarılmalıdır. Birden çok vinç aynı çalışma alanını kullanacaksa, vinçler birbirlerinin operasyon alanını işgal etmeyecek şekilde kurulumları yapılmalıdır. Aynı hattı kullanmak zorunda olan vinçlerin birbirlerine çarpmasını engellemek için, vinçlerin birbirlerine olan mesafesi limit değerlerin altına düştügünde otomatik olarak vinçlerin enerjisini kesecek bir tertibat bulundurulmalıdır. Vincin tüm bölgelerine güvenli ve kolay erişim için korkuluklar, el tutucuları ve basamaklar sağlanmalıdır. Kesinlikle askıda yükler bırakılmamalıdırlar. Yük test raporları / sertifikaları mevcut olmalıdır.

Kule vinç direği cıvataları üreticinin talimatlarına uygun bir şekilde torklanmalıdır. Aşırı yükleme limitleri test edilmeli ve doğru şekilde ayarlanmalıdır. Maksimum kabul edilebilir yük ve en son test sonuçları vinç üzerine kaydedilmelidir. Vinçlerin 3 ayda bir periyodik kontrolleri yaptırılmalıdır. Sadece eğitimli ve kalifiye operatörler kaldırma ve arma ekipmanı ile çalışılmasına izin verilmelidir. Motorlu vinçlerle operasyon esnasında yük kaldırılırken veya vincin yer değiştirme esnasında ışıklı ve sesli uyarı ikazı yapılmalıdır. İkaz sesi ortam seslerinden farklı olmalı ve kolayca duyulmalıdır. Motorlu vinçler ile gece çalışmalarında farları ve arkalarında stop lambaları yakılmalı, kabinler uygun șekilde aydınlatılmalıdır.

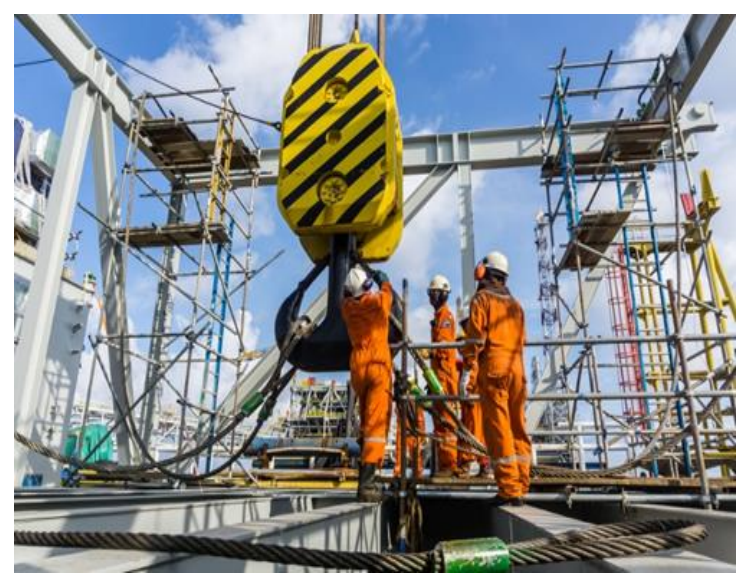

Şekil 6. Kule vinç kanca bakımı güvenli çalışma örneği

\subsection{Forklift}

Forklift operatörleri, araçların kullanımı ve bakımı ile ilgili eğitim ve değerlendirmelerinin başarılı bir şekilde tamamlanmasının ardından güvenli bir şekilde kullanmaları konusunda yetkilendirilmelidirler. 18 yaşından küçük hiçbir çalışanın forklift kullanmasına izin verilmemelidir. Forkliftler, fren, korna, direksiyon, çatal ve lastiklerin uygun durumu için günlük olarak kontrol edilmelidir. Aracın kapasitesini ve güvenli çalışmasını etkileyen herhangi bir değişiklik veya ekleme için forklift üreticisinin yazılı onayı alınmalıdır. Kapasite, çalıştırma ve bakım talimatı plakaları, etiketleri veya çıkartmaları, araca herhangi bir değişiklik veya ekleme yapıldığını göstermek için değiştirilmelidir. Araçların akü şarjı, bu amaç için özel olarak belirlenmiş alanlarda gerçekleştirilmelidir. Rampaya tırmanırken daima ileri, inerken de geriye doğru hareket edilmelidir. Yüzeyin eğimli olduğu yerlerde yük kaldırılmamalı ve manevra yapılmamalıdır. Yeniden takılan aküler uygun bir şekilde forklifte yerleştirilmeli ve emniyete alınmalıdır. Akü şarj alanlarında sigara içmek yasaktır. Akü şarj alanlarındaki açık alevleri, kıvılcımları veya elektrik arklarını önlemek için güvenlik önlemleri alınmalıdır. Forklift operatörlerinin güvensiz bir şekilde araç kullanıldığın tespiti halinde tekrar güvenli sürüş eğitimi verilmelidir. Forklifti kullanmak için yeni bir operatör atandığında operatör gözlemlenerek ayrıca 
Yapı İsleri Saha Uygulamalarının İs Güvenliği Risklerinin Değerlendirilmesi Ve Önlevici Kontrol Metodu Uygulaması bir değerlendirme yapılmalıdır. Forklift boş iken çatallar tamamen indirilmeli ve park konumuna alındığında fren tertibatı kontrol edilerek el freni çekildiğinden emin olunmalıdır. Kullanma talimatlarına, güvenlik uyarılarına ve tüm uyarıcı işaretlere uyulmalı, forklift hareket halindeyken el ve ayaklar kabin dışına çıkarılmamalıdır. Operatörü düşen cisimlere karşı korumak için forkliftte baș üstü korumalar mevcut olmalıdır. Forkliftler güvenli bir hızda çalıștırılmalıdır. Tüm yükler sabit, güvenli bir şekilde düzenlenmeli ve forkliftin nominal kapasitesi dahilinde tutulmalıdır. Güvensiz ve arızalı forkliftler servisten çıkarılmalıdır. Güvensiz/dengesiz yükler taşınmamalıdır. Yük çatallara dengeli olarak dağılmalı, tek çatalla yük taşınmamalıdır. Kapalı alanlarda çalışan forkliftlerin geliş - gidiş yolları işaretlenmelidir.

\section{SONUÇLAR}

İşverenler ve sorumlu mühendisler yapı ve inşaat projesinin çeşitli aşamalarında, inşaat işinin ve tüm bileşen aşamalarının planlandığı ve işin güvenli bir şekilde ve işçilerin sağlığını tehlikeye atmadan gerçekleştirilebilmesini sağlamalıdır. Uzman yetkililer inşaat projesinde yer alan tehlikeleri ve riskleri ve iş güvenliği ve sağlığı ile ilgili bilgileri içeren bir güvenlik belgesi hazırlamalıdır. Ayrıca uzmanlar, güvenlik dokümanının proje süresince güncel tutulmasını sağlamalıdır.

İnşaat işi bir inşaat projesine başlanmadan önce, ana yüklenici iş güvenliği ve şantiyenin kullanımı ile ilgili yazılı planlar hazırlamalıdır. Bu planlar, daha sonra mümkün olduğunca güvenli hale getirmek için bina işinin çeşitli aşamalarını düzenlemek için kullanılmalıdır. Ayrıca, işin şantiyede çalışanlar veya bina çalışmasından etkilenenler için herhangi bir tehlikeye yol açmaması da sağlanmalıdır.

Ana yüklenici, iş güvenliği ve şantiyenin geliştirici için planlarını geliştiriciye sunmalı ve planları güncel tutmalıdır. Ana yüklenicinin, her şantiyede şantiye güvenliğinden sorumlu bir kişi ataması gerekir. Bu kişinin görevleri yeterli detayda belirtilmelidir ve işvereni, görevlerine yeterli derecede nitelikli ve eğitimli olduğundan ve görevlerini yerine getirmek için yeterli yetkiye sahip olduğundan emin olmalıdır. İşin veya kullanılan ekipmanın neden olduğu tehlikeleri araştırmak ve önlemek amacıyla, şantiyede en az haftada bir saha denetimi yapılmalıdır. Günümüzde, bu haftalık saha denetimleri sıklıkla Türkiye barometresi olarak bilinenler kullanılarak gerçekleştirilmektedir. İşçilerin seçtiği bir temsilcinin denetimlere katılmasına izin verilmelidir Örneğin, ister mekanik ister manuel olsun, şantiyede yapılacak herhangi bir kaldırma ve hareket, kazaları ve kişisel yaralanmaları önlemek için önceden planlanmalıdır.

\section{KAYNAKLAR}

Akboğa, Ö., “İnşaat İș Kazalarında Lojistik Regresyon İle Kaza Şiddetinin Modellenmesi”, Doktora Tezi, Ege Üniversitesi, İzmir, Türkiye, 2014.

Cameron I, Hare B, Davies R. "Fatal and major construction accidents: A comparison between Scotland and the rest of the Great Britain”, Safety Science 46, 692-708, 2008.

Çalışma ve Sosyal Güvenlik Bakanlığl, "Yapı İşlerinde İş Sağlığı ve Güvenliği Yönetmeliği", http://www.resmigazete.gov.tr/eskiler/2013/10/20131005-2.htm,10.10.2018.

Grant A, Hinze J. "Construction worker fatalities related to trusses: An analysis of the OSHA fatality and catastrophic incident database", Safety Science, 65, 54-62, 2014

Görgülü, M.,Yapı üretiminin temel aşamalarında alınacak sağlık ve güvenlik önlemlerinin geliştirilmesine yönelik bir öneri, Yüksek Lisans Tezi, Çukurova Üniversitesi, Fen Bilimleri Enstitüsü, Sayfa: 17-20, Adana, 2008. 
Gürcanlı GE. "İnşaat Sektöründe Gerçekleşen Ölüm ve Yaralanmaların Analizi”, Mesleki Sağlık ve Güvenlik Dergisi, 13(48), 2015.

Gürcanlı GE, Müngen U. "Analysis of Construction Accidents in Turkey and Responsible Parties", Industrial Health 51, 581-583, 2013.

Gürcanlı, GE. "İnşaatlarda Tasarım Yoluyla İş Güvenliği. IMO Yayını Türkiye Mühendislik Haberleri”, 1(469), 56-68, 2011.

Gürcanl, GE. İş Güvenliği Yönetimine Giriş ve Temel İlkeler, Şantiyelerde İş Güvenliği Yönetimi Kursu Notları, İTÜ SEM, 2008.

Gürcanlı GE, Müngen U. "Fatal traffic accidents in the Turkish construction industry", Safety Science 43, 5(6), 299-322, 2005.

Gürcanlı GE, Müngen U. "Comparison Of Different Occupational Safety Codes For Construction Safety Management. Gürcanlı", 6th International Congress on Advances in Civil Engineering, İstanbul, Türkiye, 0609 Kasım 2004.

Hafızoğlu, E., "Bina Yapımında Yaşanan Kazalar ve Bir Risk Değerlendirme Çalışması”, Yüksek Lisans Tezi, İTÜ, İstanbul, Türkiye, 2006.

Hola B, Szostak M. "Analysis of the Development of Accident Situations in the Construction Industry", Procedia Engineering, 91, 429-34, 2014.

Kazan, E. "Analysis of Fatal and Nonfatal Accidents Involving Earthmoving Equipment Operators and OnFoot Workers”, Doktora Tezi, Wayne State University, Detroit, United States of America, 2013.

Mayhew C. "Health and safety in construction procurement", A Handbook For The Public Sector, 2003.

Nyirenda V, Chinniah Y, Agard B. "Identifying Key Factors for an Occupational Health and Safety Risk estimation Tool in Small and Medium-size Enterprises”, IFAC Papers Online 48, 541-6, 2015.

Saat, M.B., iş sağlığı ve güvenliği risk değerlendirme metodlarından kontrol listesi ve matris metodlarının entegre biçimde bir inşaat şantiyesinde uygulanması, Gazi Üniversitesi Fen Bilimleri Enstitüsü, 2009.

Sousa V, Almeida N, Dias L. "Risk-based management of occupational safety and health", Safety Science 66, 75-86, 2014.

Pinto A, Nunes IL, Ribeiro R. "Occupational risk assessment in construction industry-Overview and reflection", Safety Science 49, 614-24, 2011.

Yoon SJ, Lin HK, Chen G, Yi S, Choi J, Rui Z. "Effect of Occupational Health and Safety Management System on Work-Related Accident Rate and Differences of Occupational Health and Safety Management System Awareness between Managers in South Korea's Construction Industry". Safe Health Work 4, 201-9, 2013.

Zhou Z, Goh YM, Li Q. "Overview and analysis of safety management studies in the construction", Safety Science 72, 337-50, 2015. 